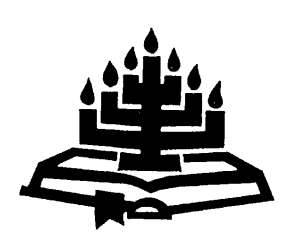

\title{
Die predikant as teiken - profiel van iemand wat emosionele wonde toedien
}

\author{
S.F. Kruger \& C.J.H. Venter \\ Vakgroep: Praktiese Teologie \\ Skool vir Kerkwetenskappe \\ Potchefstroomkampus \\ Noordwes-Universiteit \\ POTCHEFSTROOM \\ E-pos: sfk@lantic.net \\ E-pos: kwscjhv@puknet.puk.ac.za
}

\begin{abstract}
A minister as target - profile of a person inflicting emotional wounds
\end{abstract}

This article focuses on the personality of someone who intentionally wounds a minister of the Word. The typical profile of someone who wounds emotionally, and the behavioural process that usually characterises his acts are highlighted. At the meta-theoretical level the interpersonal style of a wounder is examined by applying viewpoints of Interpersonal Theory - a subsection of Personality Psychology. The specific behavioural style of a wounder comprises characteristics such as being dominating, competitive, distrusting, cold and hostile. The basis-theoretical survey conducted in this article focuses on the relationship between Paul and the Corinthian church with specific reference to the underlying relational tension. This survey reveals that the effective functioning of a congregation as a community of faith and love is of utmost importance in the identification of the personality type of the person who intentionally wounds a minister of the Word. In conclusion an analysis for understanding, as well as guidelines for coping with the whole situation is proposed. The reaction of a minister and a congregation's understanding of the nature of the wounding process are outlined as being of specific importance.

\section{Opsomming}

Die predikant as teiken - profiel van iemand wat emosionele wonde toedien

Hierdie artikel fokus op die persoonlikheidstipe van iemand wat 'n Woordbedienaar doelbewus verwond. Die tipiese persoonlik- 
heidsprofiel van iemand wat emosionele wonde toedien en die tiperende eienskappe wat hierdie verwondingsproses gewoonlik begelei, word benadruk. Op metateoretiese vlak word die verwonder se interpersoonlike styl ondersoek aan die hand van uitgangspunte uit die Interpersoonlike Teorie - 'n onderdeel van Persoonlikheidsielkunde. Die verwonder se spesifieke gedragstyl sluit gewoonlik die volgende in: hy is dominerend, kompeterend, wantrouig, koud en vyandig. Vir die doeleindes van hierdie artikel word 'n basisteoretiese ondersoek onderneem waarin spesifiek gefokus word op Paulus se verhouding met die gemeente van Korinte in die lig van die onderliggende verhoudingspanning. Die ondersoek bring aan die lig dat die effektiewe funksionering van die gemeente as 'n geloof- en liefdesgemeenskap 'n baie belangrike faktor is in die identifisering van die persoon wat die bedienaar van die Woord intensioneel verwond. Ten slotte word 'n verstaansanalise en praktiese hanteringsriglyne voorgestel. Die reaksie van die bedienaar sowel as die begrip van die gemeente vir die aard van die verwondingsproses word hierin betrek.

\section{Inleiding en aktualiteit}

Hierdie artikel bring breedweg verhoudings binne die kerklike praktyk, naamlik die verhouding tussen die bedienaar van die Woord en sy gemeente in die visier. Die aard van hierdie verhouding gaan die produktiwiteit en effektiwiteit van die bedienaar, sowel as die bedieningsuitkomste grootliks bepaal.

Die spesifieke fokus word hier egter gerig op situasies waar die predikant die teiken word van 'n verwondingsproses - 'n aftakelingsproses deur 'n deel van die gemeente, of deur 'n enkele lidmaat. Hierdie verwonding geskied deur 'n spektrum van negatiewe aksies teen die predikant te loods. In dié proses word die predikant dan die teiken van die verwonding. So kan byvoorbeeld bloot negatiewe insinuasies lei tot verwonding. Meer blatante vorme van verwonding waar die predikant se bediening en persoon as teiken geneem word, kan die volgende insluit: verdagmakery, openlike aanvalle en verwerping. In die praktyk kan hierdie verwonding realiseer in die beklemtoning van sogenaamde leemtes in die bedienaar se preke. Aanvalle kan geloods word onder die dekmantel dat die bedienaar byvoorbeeld nie die Heilige Gees in sy preke betrek nie, dat die klem op gelowiges se persoonlike verantwoordelikheid die versoeningswerk van Christus onderbelig, dat die mens te sentraal staan in die toepassing van preke, ensovoorts. Die bedieningskwaliteit van die bedienaar kan ook in bedekte aanvalle getipeer word as nie vernuwend of behoudend 
genoeg nie. Op praktiese vlak kan die predikant beskuldig word dat hy nie omsien na die kerk se finansies nie; dat hy hom nie steur aan die jeug in die gemeente nie. Die verwonder is gewoonlik heel skerpsinnig en sal dikwels sy beskuldigings gooi oor die boeg dat hy maar net staan vir die waarheid van die Woord en dat die gesag van die Woord nie aangetas moet word nie.

Wanneer die persoon van die predikant so afgebreek word, is die emosionele pyn dikwels dieper as enige fisiese pyn (vgl. Ekman, 2001:160). Die predikant kan 'n psigiese knak toegedien word wat hom sy lewe deur gaan bybly. Sy fisiese gesondheid, sy roeping, loopbaan, finansiële posisie, toekoms en dikwels sy geloof en geloofslewe word geraak. Nie alleen word die persoon van die predikant verwond nie, maar ook sy gesinslede (vgl. Roux, 1992: 230). Hierdie artikel wil ook begrip kweek vir die omvang en intensiteit van hierdie tipe skade.

Voorts sal gepoog word om insig te bied in die ontwrigtende en inhiberende effek van verwonding op die effektiewe funksionering van die predikant. 'n Predikant se kosbare tyd en energie word in so 'n situasie opgeslurp deur aspekte van 'n spanningsvolle verhouding. Bedieningseffektiwiteit, 'n wesensdimensie binne die opbou van die kerk en uitbreiding van die koninkryk, word erg aan bande gelê. God se saak op aarde kan ingrypend ontwrig en benadeel word indien die Woordbediener die teiken word van ' $n$ vernietigende konteks en verwonding.

Alhoewel verwonding gewoonlik 'n komplekse saak met verskeie oorsake is, kan die primêre aanleiding in een van twee partye setel:

- óf by die predikant, wat deur sy optrede en styl ooglopend negatiewe reaksie ontlok (vgl. Venter, 2004:429-449),

- óf by die die gemeente (of 'n enkeling in die gemeente) wat sonder noemenswaardige provokasie die verwondingsproses aan die gang sit.

In hierdie artikel gaan laasgenoemde scenario behandel word.

Die oogmerk is om hierdie primêre aanleiding tot verwonding te analiseer en om vas te stel in hoe 'n mate hierdie basiese instigent as faktor in die kerklike praktyk geneutraliseer kan word. Daar gaan dus eerstens gefokus word op die persoon in die gemeente wat die verwonding aanstig - 'n patologiese antagonis - so genoem deur Greenfield (2001:16), en tweedens op die rol van die res van die gemeente. 
Die metode wat gevolg gaan word is om

- op metateoretiese vlak gebruik te maak van die navorsingsresultate van die Persoonlikheidsielkunde ten opsigte van die Interpersoonlike Teorie;

- op basisteoretiese vlak die lig te laat val op Paulus se verhouding met die gemeente van Korinte;

- op praktykteoretiese vlak 'n verstaansanalise te bied en hanteringsriglyne voor te stel.

Dit is egter nodig om vooraf die manifestasie van die probleem van nader te bekyk.

\section{Die persoon en proses}

\subsection{Tiperende eienskappe van die verwonder}

Greenfield, wat self 'n teiken van verwonding was, het uitgebreide navorsing gedoen oor die persoon en optrede van die verwonder. In hierdie verband het Emery en Oltmanns (1999:246-247) ook waardevolle bydraes gelewer. Greenfield (2001:28) beskryf die tipiese eienskappe van die verwonder vanuit sy eie subjektiewe ervaring (met verstaanbare gepaardgaande emosie) soos volg.

Hy [die verwonder] is destruktief in sy optrede; hy is vasberade, misleidend vals en selfs demonies [met laasgenoemde term bedoel Greenfield dat die verwonder psigies wanaangepas of versteurd is - outeurs]; voorts is hy 'n meester van manipulasie (en gebruik dikwels die reëls van ordentlikheid en oënskynlike besorgdheid); hy is bedrewe in die kuns van vermomming deur naïewe kerkgangers agter 'n masker van vroomheid en toewyding te beïnvloed. Die probleem is dat lidmate so 'n persoon kan verwar met 'n yweraar wat vanuit oënskynlik goedbedoelde motiewe die behoud van die kerk voor oë het. Sy oogmerk hou egter verband met die sug na en verkryging van mag in die kerk. (Eie vertaling.)

\subsection{Die proses van verwonding}

Die proses van verwonding verloop gewoonlik soos volg (vgl. Greenfield, 2001:36, 55):

- Die verwonder navigeer sy weg tot in een of meer sleutelposisies in die kerk (en almal is dankbaar dat hier 'n aktiewe lidmaat is wat bereid in om te help). "They are thriving on being the center of attention. They are self-centered, vain and demanding and they 
constantly seek approval from others" (Emery \& Oltmanns, 1999: 247).

- Hy inisieer ontwrigting deur een of ander probleem te identifiseer. $\mathrm{Hy}$ is gewoonlik hipersensitief vir enige oënskynlike tenakoming, soos wanneer hy oorgeslaan word vir die weeklikse gebedsopening van samekomste, of wanneer daar nie gereeld met hom gepraat word tydens informele kuiergeleenthede nie, of wanneer sy opinie oor 'n saak nie spesifiek gevra word nie. Sulke verstaanbare oorsigtelikhede vertolk hy as 'n persoonlike aanval of as 'n manifestasie van verwerping.

- Mettertyd vergader die verwonder 'n groepie mense rondom hom. Hierdie mense word uitgesoek aan die hand van hulle kortsigtigheid, naïwiteit en oordrewe sentimentaliteit. Met baie emosie word hulle ondersteuning gewerf. Die verwonder het meermale 'n duidelike geskiedenis van redelik intense, maar onstabiele verhoudings met ander (vgl. Wade \& Tavris, 2003: 597).

- Uiteindelik loods hy 'n aksie waardeur hy die predikant as sy teiken neem en subtiel aanval. In dié proses kan die verwonder baie passievol wees en in harde taal stel dat hy die "vyand" (predikant) beveg en nie sal rus totdat hy tot ander insigte kom of selfs "vernietig" (uitgeskakel) is nie. In die proses gebruik die verwonder gewoonlik een of ander geestelike motief om die gemeente aan sy kant te kry, terwyl sy werklike motief verband hou met selfsug, mag en beheer. Sy aanvalle is ook baie meer persoonlik as saaklik. Hy maak 'n groot saak van 'n minder belangrike beuselagtigheid (trivialisme) en bied ook sterk bewyse aan vir nie-tersaaklike dinge. Hy maak kwistig gebruik van oordrywing. Daarby gebruik hy ook die argumentum ad ignoratium, naamlik om aanspraak te maak dat 'n aantyging die waarheid is bloot omdat dit nie weerlê kan word nie. Laastens maak hy hom skuldig aan blatante falsifikasie deur onwaarhede te versprei.

\subsection{Op grond waarvan kan dié proses voorkom?}

Wat hierbo ontleed is, spreek veel, veral as ' $n$ mens in gedagte hou dat persoonlikheid kommunikeer. Persooonliheidsdisfunksies kommunikeer dus ook en so kan verwondingsprosesse tot stand kom (Nel, 2001:13-42).

Greenfield (2001:54, 59 e.v.) vra ook die vraag hoe dit gebeur dat so 'n "siek" lidmaat die kerklike domein binnekom en skynbaar 
ongehinderd skade aanrig. Hy gee vyf insiggewende redes vir hierdie situasie:

- Die moontlike naïwiteit van die lidmatekorps (insluitende ampsdraers) wat die werklikheid van subtiele demoniese kragte in 'n hedendaagse opset onderskat.

- 'n Gemeente se preokkupasie met die instandhouding van die "organisasie". Strukture en prosesse word oorbeklemtoon, dikwels ten koste van bediening, lewende verhoudings en uitreik na mekaar.

- 'n Oorbeklemtoning van administratiewe aktiwiteite binne die gemeente. Kerkleiers ken aan hulleself 'n administratiewe funksie toe, eerder as 'n bedieningsrol. Administrasie word sodoende ' $n$ motief en doelwit op sigself.

- 'n Gemeentelike ingesteldheid van ordentlikheid en om tevrede te stel. 'n Onderlinge verabsolutering van tevredenheid en rustigheid in die gemeente bring mee dat iemand nie maklik gekonfronteer word nie. 'n Verkeerde verstaan van liefde en aanvaarding van mekaar kan lei tot 'n ongesonde verdra van sondige motiewe.

- Die passiwiteit van leiers in die gemeente.

Dit is duidelik dat 'n kerk wat oormatig klem plaas op formele aspekte van kerkwees dit vir die verwonder baie maklik maak om die predikant as teiken te kies en te verwond.

\section{Die Interpersoonlike Teorie - 'n metateoretiese verkenning}

\section{1 Motivering}

Onder hierdie punt word 'n moontlike profiel van die verwonder, soos hierbo beskryf is, nader ondersoek. Sy abnormale optrede hou dikwels verband met twee faktore: sy magsug en sug na kontrole sowel as sy antagonistiese en polemiese ingesteldheid. Hierdie tweeledige disposisie verteenwoordig 'n disfunksionaliteit en word gaandeweg 'n deurlopende patroon. Daarom gaan hy waarskynlik die verwonde predikant se opvolger, en dié se opvolger ook verwond.

Die beskrywing van die profiel van die verwonder laat twee aspekte uitstaan: 
- Eerstens het ons te doen met gedragspatrone wat deurlopend voorkom en gevolglik 'n tipiese en kenmerkende styl geword het.

- Tweedens manifesteer hierdie styl nooit in 'n lugleegte nie. Die verwonder wil sy eie relatiewe status en mag verhoog en die enigste konteks waarbinne dit kan geskied is in 'n interpersoonlike verhouding. Die verwonder is dus afhanklik van sodanige verhouding om sy doel te bereik.

Wanneer deurlopende of tipiese en kenmerkende gedrag van 'n persoon ter sprake is, val hierdie gedrag op die terrein van die Persoonlikheidsielkunde. Persoonlikheid het immers te doen met die vaste denk- en gedragspatrone wat min of meer deurlopend by 'n persoon voorkom, wat aan hom 'n eie, unieke en uitkenbare identiteit gee (vgl. Allport, 1961:28; Eysenck \& Eysenck, 1985:9; Möller, 1996:6; Kruger, 2000:82, 83; Kruger, 2004:21).

Menslike persoonlikheid bevat verskillende fasette en kan ondersoek word vanuit verskillende teoretiese oriëntasies (Kruger, 2000:37). Elke persoonlikheidsteorie moet verstaan word binne sy eie oriëntasie of gesigspunt. So kan persoonlikheid byvoorbeeld ondersoek word vanuit die gesigspunt van 'n deurlopende temperament, gedragsvaardighede, aanleg of interpersoonlike styl. Nie alle persoonlikheidsteorieë kan in die bestek van hierdie artikel aan die orde kom nie, en daarom word 'n keuse gemaak ten gunste van die Interpersoonlike Teorie in die lig van die tweede aspek van die verwonder se profiel, soos hierbo aangetoon. Interpersoonlike Teorie bestudeer interpersoonlike style soos wat dit deurlopend by 'n persoon voorkom. Hierdie teorie fokus nie alleen op goed aangepaste interpersoonlike style nie, maar ook op wanaangepaste en patologiese manifestering van hierdie style. Faktore soos komplementerende of nie-komplementerende style by partye in 'n verhouding is veral van waarde.

Weaver (2002:401) was deel van 'n span wat in die VSA 'n ondersoek gedoen het na die geestelike gesondheid van bedienaars. $\mathrm{Na}$ afloop van die ondersoek was hulle heel eerste aanbeveling dat teologiese studente bewus gemaak behoort te word van die druk wat die bediening meebring, "particularly in terms of interpersonal dynamics".

\subsection{Aanloop en oorsig}

Sullivan (1892-1949) was die eerste psigoloog wat 'n sistematiese interpersoonlike teorie (Sullivan, 1953:110-111) en etiologie (Sullivan, 1955:20, 21) van persoonlikheid geformuleer het (vgl. 
Aiken, 1993:149). Leary (1920-1996) ontwikkel Sullivan se teorie verder en skryf op 37-jarige ouderdom 'n standaardwerk oor interpersoonlike persoonlikheid, Interpersonal Diagnosis of Personality (1957). Carson bou hierop voort met sy werk Interaction Concepts of Personality (1970). 'n Baie gesaghebbende bron is dié van Kiesler, Contemporary Interpersonal Theory and Research. Personality, Psychopathology and Psychotherapy (1996).

Sullivan se teorie bestaan uit 'n beskrywing sonder 'n noemenswaardige empiriese onderbou. Leary het sterk gefokus op 'n model wat 'n onderbou van empiriese navorsing, wat oor twee jaar gestrek het, bevat (die sg. oktale sirkumpleks). Hierdie empiriese navorsing is deur Kiesler as basis gebruik is vir sy sogenaamde 16segmentsirkumpleks wat 'n baie bruikbare instrument geword het en wat vervolgens aan die orde gestel sal word.

\subsection{Die sirkumpleks}

\subsubsection{Ontstaan en meganika}

'n Sirkumpleks is 'n sirkelvormige konfigurasie, struktuur, model of voorstelling van interpersoonlike style, wat die ooreenstemming of verskil (polariteit) weerspieël, sowel as die intensiteitsgraad (gematigd of ekstreem) van 'n bepaalde styl. Elke persoonlikheidstipe word voorgestel deur 'n lyn (of kontinuum) vanaf die middelpunt van die sirkel tot aan die rand daarvan. Kwalitatiewe variasies (of intensiteitsgraad) binne 'n spesifieke styl word uitgedruk in terme van die afstand vanaf die middelpunt van die sirkel, sodat die goed aangepaste vorm nader aan die middelpunt geplaas is, en die wanaangepaste vorm nader aan die buitenste rand (Carson, 1970:107). Hierdeur word die indeks van afwyking grafies aangetoon (vgl. ook Emery \& Oltmanns, 1999:241 vir 'n verwysing na die waarde van die DSM-IV diagnostiese riglyne).

Die ontwerpers van die sirkumpleks het 'n omvattende lys transitiewe werkwoorde saamgestel wat almal interpersoonlike gedrag beskryf. Dit is in verband gebring met interpersoonlike motiewe wat saamgegroepeer is in 'n aantal generiese groepe. In die beskouing van die generiese motiewe is gevind dat elkeen verband hou met twee basiese faktore: 'n mag-/statusfaktor en/of 'n affiniteits-/afstandsfaktor. Hierdie mag- en affiniteitfaktore is op twee asse (of kontinuums) in die sirkumpleks voorgestel. Die eerste as (in hierdie geval die grafiese $y$-as of vertikale as) wat krag of status aandui, word die dominerend-onderdanige as genoem en die tweede (die grafiese $x$-as of horisontale as) wat affiniteit aandui, 
word die vyandig-vriendelike as genoem. Die twee asse of lyne waardeur hierdie twee basiese dimensies voorgestel word, kruis mekaar om 'n kwadrantskema te vorm wat met die volgende tweedimensionele skema voorgestel word:

Dominerend

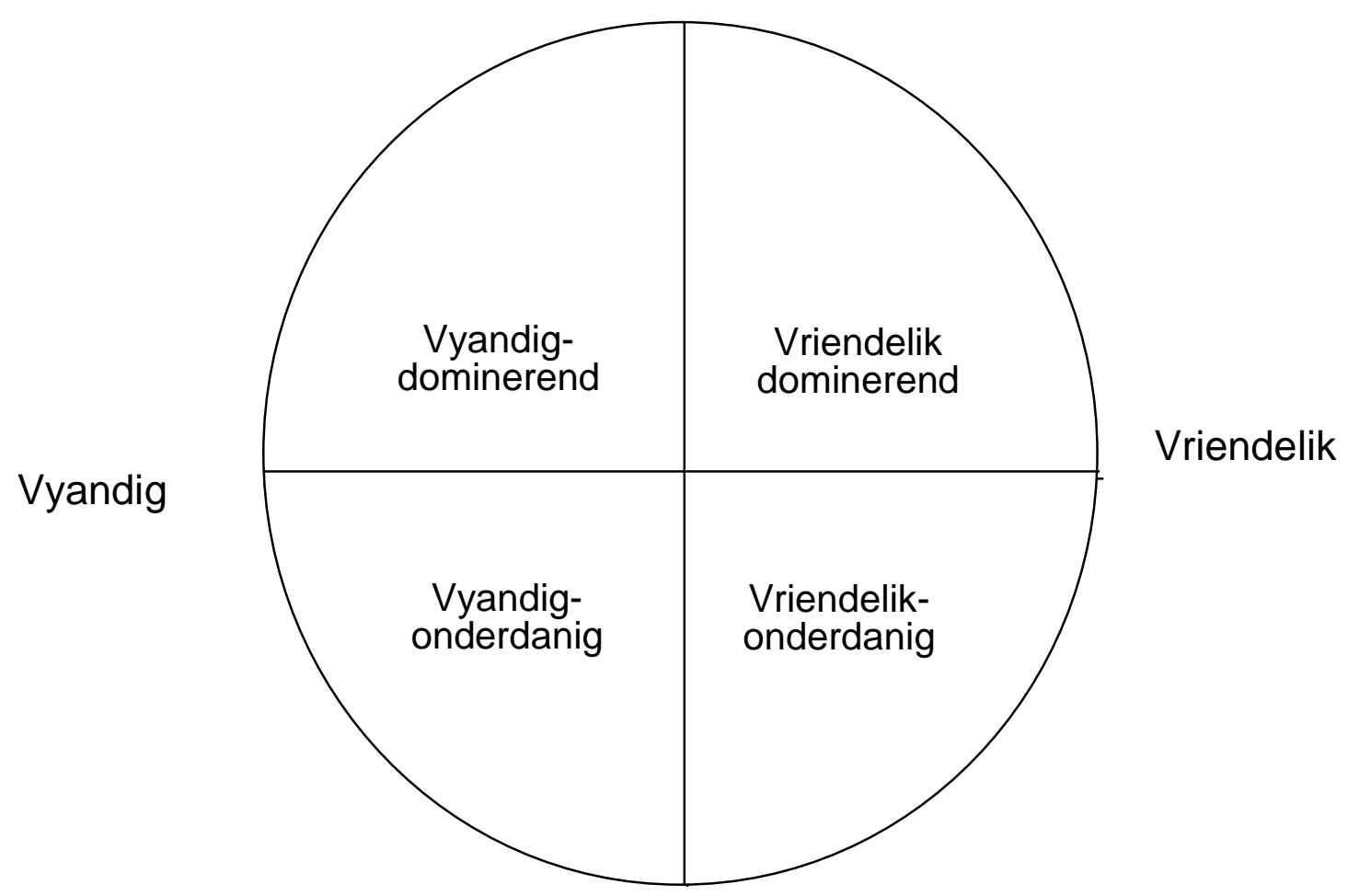

Onderdanig

\section{Figuur 1 - Die kwadrantskema}

Elke mens voel gemaklik en selfversekerd iewers tussen uiterste dominering en uiterste onderdanigheid (die vertikale kontinuum) en tussen uiterste vyandigheid en uiterste vriendelikheid (die horisontale kontinuum). Wanneer 'n persoon se posisie op hierdie twee lyne gekombineer word (die koördinate vasgestel word), kan sy persoonlikheid ook uitgedruk word in terme van een van die vier kwadrante hierbo.

\subsubsection{Vyf tersaaklike style}

Die tipiese verwonder maak hom skuldig aan magsug (dominering) sowel as antagonisme (vyandigheid). Sy interpersoonlike styl val 
dus duidelik in die vyandig-dominerende kwadrant. Kiesler het hierdie kwadrantmodel uitgebrei tot 'n 16-segmentsirkumpleks, wat meebring dat hy binne elke kwadrant nog drie style identifiseer. Daar word volstaan met die verwysing na Kiesler aangesien hy die 16-segment sirkumpleks ontwikkel het. Die meeste ander gedragswetenskaplikes gebruik hierdie omlyning of definiëring van Kiesler.) Die vyandig-dominerende styl differensieer dan in die volgende vyf style, wat hieronder behandel word, telkens ten opsigte van die wanaangepaste manifestasie daarvan (Kiesler,1996:17 e.v.).

\subsubsection{Die dominerende persoonlikheid}

In sy ekstreme manifestasie is hierdie persoonlikheid dominerend en vermetel. Hy oorheers ander en het 'n tipiese sersant-majoorhouding. Hy stoomroller ander en dring aan op hulle inskiklikheid en onderdanigheid. Hy val ander in die rede, gee gedurig voorskrifte aan ander en verhef sy eie standpunte tot 'n onomstootlike dogma. Hy weerstaan op kragdadige wyse enige voorskrifte wat van die kant van ander vir hom bedoel is. Hy is verder sterk, onversetlik, rigied en sal baklei vir die handhawing van sy eie standpunt. Die indruk wat hy op ander maak, is dié van 'n vermetele, heerssugtige diktator.

Hierdie manifestasie kan vergelyk word met 'n despoot en despotisme. Veral sy sug na mag en beheer is tipies van die verwonder in die gemeente.

\subsubsection{Die kompeterende persoonlikheid}

In sy ekstreme manifestasie is hierdie persoonlikheid 'n kragtige wedyweraar. Hy kan nie ophou werk nie en laat hom deur niks stuit nie. Hy het 'n drang om te produseer en iets te bereik ter wille van sukses, aansien en geld. Hy kompeteer meedoënloos met ander en is daartoe verbind om ten alle koste te wen. Hy eis alle krediet vir homself op en maak ander se bydraes af as minderwaardig. Hy buit ander uit vir persoonlike gewin. Die indruk wat hy op ander maak, is dié van 'n waaghalsige mens, slu, sterk gemotiveerd en 'n werksverslaafde.

Hierdie styl in sy ekstreme vorm kan vergelyk word met die patologiese antagonis se blinde vasberadenheid en geneigdheid tot falsifikasie. 


\subsubsection{Die wantrouige persoonlikheid}

Hierdie tipe persoonlikheid is paranoïed en haatdraend in sy ekstreme manifestasievorms. Enige hulp sien hy as 'n bedreiging. $\mathrm{Hy}$ sien persoonlike gevaar in alles. Hy is vasberade om ander se vermeende selfsugtige bedoelings te ontmasker, twyfel aan ander se lojaliteit, toets ander en spioeneer dikwels op hulle. Sy eie gedrag verberg hy en is ontwykend. Hy vind dit moeilik om selfs minder skadelike optrede teen hom te vergewe. Hy veroordeel ander omdat hulle hom vals beskuldig, verdink ander dat hulle teen hom saamsweer en beskuldig hulle dat hulle hom agtervolg. Die indruk wat hy op ander maak, is dié van 'n bedrieglike, liggeraakte en wraaksugtige mens.

Hierdie styl se patologiese vorm is dié van 'n paranoïede persoon (vgl. Widiger \& Hagemoser, 1997:310) wat vergelyk kan word met die tipiese verwonder se hipersensitiwiteit vir enige moontlike aksie waardeur hy oënskynlik te na gekom sou word. Persoonlike motiewe teen homself word in die optrede van ander gesien.

\subsubsection{Die koue persoonlikheid}

Hierdie persoonlikheid is in die duidelikste waarneembare vorm uitermate krities, onbillik in sy beoordeling van ander en 'n konstante foutvinder. Hy vereis absolute nakoming van die reëls en dring aan op streng dissipline en strafmaatreëls. Sy beoordelingsmaatstawwe is onbuigbaar. Hy verag verskonings en veroordeel ander vir foute en vereis vergoeding in geval van verkeerde optrede. Hy kom voor as iemand wat nie die vermoë het om ander te waardeer en aan te prys nie. Die betoning van wamte het geen invloed op hom nie. Die indruk wat hy op ander maak, is dié van 'n dikvellige, koudhartige en genadelose mens.

Hierdie styl se patologie hou verband met psigopatie. Die psigopaat is die persoon by wie ' $n$ mens geen gewetenswerking kan opmerk nie en wat tipies agter 'n indrukwekkende masker leef.

\subsubsection{Die vyandige persoonlikheid}

In die uiterse gevalle is hierdie persoonlikheid haatdraend en sadisties. Hy is geneig om ander se regte blatant te ignoreer en te vertrap. Hy sal ander selfs gewetenloos aanval. Met 'n element van wraakgierigheid sal hy drasties verskil met ander, onbeskof op hulle skreeu en hulle uitskel. Hy is opstandig oor opdragte en sal ander se aktiwiteite aggressief dwarsboom. Hy sal op polemiese wyse enige hulp van die hand wys terwyl hy ander onversigtig aanspreek en 
beledig. Hy skyn vasberade te wees om ander te misbruik en seer te maak en vind selfs behae daarin dat hulle seerkry. Die indruk wat hy op ander maak, is dié van 'n rebelse, venynige en gemene mens.

Hierdie styl kan vergelyk word met die verwonder se oordrewe aggressiewe en polemiese gedrag en sy patologie is dié van die skisoïede persoonlikheidsversteuring (Leary, 1957:233).

\subsection{Motiewe}

Die vraag wat hier aan die orde kom is: Watter motiewe of vormingsagente lê ten grondslag aan 'n bepaalde interpersoonlike profiel?

Die basiese motief waarmee Leary (1957:15) werk, is dié van angs en hy stel dat alle fasette van iemand se interpersoonlike gedrag 'n poging is om angs te vermy en om selfwaarde te handhaaf. Plutchik en Conte (1997:19 e.v.) beskryf die positiewe of funksionele rol van angs, maar vervang die begrip "angs" met "emosie". Hulle stel dat die natuurlike omgewing oorlewingsprobleme vir alle organismes inhou. Hierdie probleme hou verband met die manier waarop gereageer word op enige bedreiging. In hierdie verband speel emosies 'n sentrale rol om basiese aanpassingspatrone te skep, byvoorbeeld veg- of vluginstink (vgl. Goleman, 1997:194-199.). Funksionele emosies word dan oorgedra deur middel van 'n redelik permanente persoonlikheidstrek. Persoonlikheidstrekke is standhoudende uitdrukkings van emosionele geneigdhede. Kontemporêre teoretici skryf soos volg oor angs (opsommend en samevattend):

Die basiese motiveerder van persoonlikheid is die minimalisering van onsekerheid (Kiesler, 1996:54; Wiggins, 1996:113) en die vermyding van angs (Möller, 1996:329; Aiken, 1993:15; Safran \& Segal, 1990:70 e.v.). 'The concept of anxiety is among the most central, and is certainly the most all-inclusive of the concepts in Sullivan's system' (Wiggins, 1996:110).

Carson (1970:233) merk op dat mense met persoonlikheidsversteurings nie noodwendig 'n ander stel motiewe het wat hulle gedrag bepaal nie. Dieselfde motiewe word slegs op ander wyses hanteer: hulle maak die meeste van hulle interpersoonlike matriks wat beskikbaar is om angs te hanteer.

Moontlike angsveroorsakende emosies en situasies is die volgende: 
- Angs vanweë 'n gevoel van hulpeloosheid en gevaar

- Angs vanweë verwerping, isolasie en swakheid

- Angs vanweë die verlies van selfwaarde (vgl. Sullivan se siening soos by Leary, 1957:8).

\subsection{Komplementariteit}

Die beginsel van komplementariteit word beheer deur bepaalde wetmatighede (vgl. Duke \& Nowicki, 1982:79). Op die $x$-as (affiniteit - vgl. Figuur 1) word 'n reaksie (of respons) getoon wat ooreenstem met die aanvanklike gedrag (of motiewe). Vriendelikheid ontlok dus vriendelikheid en vyandigheid ontlok vyandigheid. Op die $y$-as (krag of status) word 'n reaksie getoon wat die teenoorgestelde is as die aanvanklike gedrag. Dominering ontlok dus onderdanigheid en vice versa.

Binne 'n komplementerende verhouding ontlok motiewe wat in die kwadrant regs bo (vgl. Figuur 1) lê, response vanuit die kwadrant regs onder. Net so ontlok motiewe in die kwadrant links bo response vanuit die kwadrant links onder. Die omgekeerde geld ook: binne 'n komplementerende verhouding ontlok motiewe in die kwadrant regs onder response vanuit die kwadrant regs bo en motiewe in die kwadrant links onder ontlok response vanuit die kwadrant links bo (vgl. Kiesler, 1996:93). Dus: solank die lyne wat die rigting van die wederkerende aksie voorstel, beperk is tot óf die regterhelfte óf die linkerhelfte en dus 'n aksie van bo na onder of onder na bo aandui, maar nie van die regter- na die linkerhelfte nie of omgekeerd nie (dus: nie die $y$-as kruis nie), is dit 'n aanduiding van 'n komplementerende verhouding.

Daar is baie veranderlikes en onbestendighede sodat hierdie verskynsel van komplementariteit nie werklik 'n betroubare basis vir gedragsvoorspelling is nie (Leary, 1957:125). Die beginsel van komplementariteit waarborg dus nie 'n konsekwente komplementerende respons nie (vgl. Horowitz, Dryer \& Krasnoperova, 1997: 357). Wederkerigheid kan nie altyd beheer word nie; die ander persoon se persoonlikheid kan sy respons anders dikteer as wat die subjek dit sou verwag (Leary, 1957:325). Kiesler (1996:90) noem dit nie-komplementariteit. Nie-komplementariteit is ter sprake wanneer response nie die gevoel van angs verminder of die gevoel van sekuriteit vermeerder nie. Laasgenoemde feit is belangrik vir die verstaan van die verwonder se optrede. 


\subsection{Betekenis vir die onderwerp}

Elke mens het spesifieke voorkeurmotiewe (Leary, 1957:156). Party mense het 'n baie beperkte repertoire en ontvang gevolglik 'n ewe beperkte hoeveelheid response van ander. Die patologiese persoon het gewoonlik 'n uitermate beperkte interpersoonlike aanslag, maar wend een of twee benaderingswyses aan wat baie kragtig werksaam is (Leary, 1957:126). Sommige mense het alle interpersoonlike vaardighede verloor behalwe een: in die geval van die tipiese verwonder is dit die vaardigheid waardeur hy mag en beheer vir homself verwerf om daardeur 'n gevoel van sekuriteit te versterk (die vyandige styl is ' $n$ konsekwensie daarvan).

Die dinamika geskied gewoonlik soos volg: Wanneer die verwonder deur sy eie magsmanifestasies onderdanigheid en erkenning ontlok, is daar nie spanning nie vanweë die komplementerende aard van die verhouding. Dit sou geskied wanneer hy die erkende leier van 'n groep is. In 'n gemeente streef hy dan ook daarna om die erkende leier te wees. Die Woordbedienaar word egter normaalweg deur die gemeente as leier erken. Hierdie status van die bedienaar bring mee dat sy verhouding met die verwonder 'n nie-komplementerende verhouding is wat deur 'n magstryd gekenmerk word. Dit gaan hier oor 'n poging van die verwonder se kant om kontrole te hê oor die krag in die verhouding. ' $n$ Komplementerende verhouding bestaan immers uit twee partye met gelyke status, maar wat optree sodat die een die aksie inisieer en die ander dit volg. Daarteenoor is ' $n$ verhouding nie-komplementerend wanneer albei partye altyd inisiërend optree, en nie een wil volg nie.

'n Magstryd skep 'n antitese in die verhouding. Hierdie antitese sluit 'n antagonistiese of vyandige motief in die verwonder se styl in. Die verhoudingsdinamika verander enige verhouding wat die verwonder se status bedreig in ' $n$ vyandige verhouding. Selfs al besit die predikant en bedienaar ' $n$ soepel persoonlikheid (daar bestaan ' $n$ aantal intervensiestyle - vgl. Andrews, 1991:137 e.v.) om daardeur die verwonder se motiewe en style te akkommodeer, en so die grootste mate van komplementariteit te behou, word die verhouding nogtans nie-komplementerend bloot vanweë die algemene erkenning van status wat die gemeente (en gemeenskap) aan die predikant en bedienaar gee. Laasgenoemde veroorsaak by die verwonder 'n angs vanweë 'n verlies, of moontlike verlies van selfwaarde en dryf hom om die bedienaar uit te daag. 


\section{Paulus se verhouding met die Korintiërs - 'n basis- teoretiese verkenning}

\subsection{Motivering en agtergrond}

Onder hierdie punt word die rol van die gemeente (wat alle ampte insluit) ondersoek in die lig van die optrede van die tipiese verwonder. Die motivering vir die keuse van Paulus se verhouding met die Korintiërs, soos in die Korintiërbriewe beskryf, is dat hierdie briewe die volgende prominente interpersoonlike temas bevat:

- Daar was 'n gebrek aan eensgesindheid (1 Kor. 1:10) en partyskappe het voorgekom (1 Kor. 1:11, 3:3, 11:18) in die gemeente.

- Paulus se integriteit is bevraagteken (1 Kor. 4:3-5).

- Hy word negatief beoordeel deur sy lesers ("dié wat regter oor my speel” - 1 Kor. 9:3). Hierdie optrede deur die gemeente kan as aanvalle op Paulus beskryf word.

- Tussen Paulus en Apollos was daar 'n gewildheidstryd onder gemeentelede (1 Kor. 3).

\subsection{Perspektiewe op mag/status}

Teen bogenoemde agtergrond tree Paulus op vanuit 'n bepaalde status van hoogagting van God se werk in hom. Hierdie benaderingswyse werk eerder remediërend as kompliserend ten opsigte van die verhouding tussen hom en sy aanvallers.

\subsection{1 'n Dubbele status}

Wanneer dit vir Paulus oor God se eer of roem gaan, dan verwys hy ook na homself, maar spesifiek na God se werk in hom, wat hy hoog ag (vgl. 2 Kor. 10:8; 2 Kor. 11:30). As dit egter oor sy eie status gaan, takseer hy homself volgens sy natuurlike staat as sondaar. 'n Mens se sondebewussyn is dus 'n realiteit wat hom altyd moet bybly in sy selftaksering.

\subsubsection{Christus as rolmodel}

Die voorbeeld van Christus moet nagevolg word, aangesien dit ' $n$ grootse eer en voorreg is om soos Christus te wees (vgl. ook $1 \mathrm{Kor}$. $11: 1$; 2 Kor. 3:18) en deur jou nederige gesindheid met Hom te identifiseer en geassosieer te word. Die inhoud van Jesus se voorbeeld hou verband met nederigheid. Jesus het gekom om te dien en nie om gedien te word nie (Matt. 20:28) en op grond hiervan kan Hy die opdrag gee: "Elkeen wat in julle kring groot wil word, 
moet julle dienaar wees; en elkeen wat onder julle die eerste wil wees, moet julle slaaf wees" (Matt. 20:26, 27). Sonder geloof en 'n persoonlike verhouding met Christus sou hierdie aansporing van sy voorbeeld nie die krag hê wat dit sou hê as 'n persoonlike geloofsverhouding met Christus 'n konkrete werklikheid is nie.

\subsubsection{Objektiewe status teenoor gesindheid}

Die feit dat 'n lae status hier nie 'n objektief toegekende status verteenwoordig nie, maar 'n gesindheid waarvolgens die gelowige homself eerder laer as hoër takseer, dien as antwoord op Nietzsche se afkeur van hierdie (wat hy noem) "perverse moraliteit" wat minderwaardige Christene kweek (vgl. Grounds, 1975:222). Die goddelike taksering van die mens gee aan hom 'n status wat verstaan moet word in die lig van die onuitspreeklike liefde van God en Christus, wat die grond is van die kruisdood van Christus. Hierdie liefde impliseer 'n kosbaarheid en waarde wat God aan die mens heg, ten spyte van sy sonde. Die mens se waarde uit homself en van nature is baie laag, maar God ken aan hom 'n hoë waarde toe (vgl. 1 Kor. 4:6, 7):

In hierdie uiteensetting, broers, het ek myself en Apollos as voorbeelde gebruik om julle te leer wat die gesegde beteken: 'Hou jou binne die perke wat God gestel het.' Dan sal niemand hom belangriker as 'n ander beskou oor sy leermeester nie. Wie maak jou so belangrik? En wat besit jy wat jy nie ontvang het nie? As jy dit dan ontvang het, waarom stel jy jou so aan asof jy dit nie ontvang het nie?

\subsubsection{Betekenis vir die onderwerp}

Uit bostaande is dit duidelik dat 'n toegekende status, met inagneming van eie nederige natuurlike status, altyd nederigheid sal verseker. Geloof in God maak dit moontlik. 'n Laer posisionering deur die bedienaar op die magskontinuum (vgl. Figuur 1) maak 'n potensiële magstryd soveel onwaarskynliker. Tog lê die feit van 'n dubbele status (vgl. 4.2.1 hierbo) 'n verantwoordelikheid op die bedienaar om met die gesag van die Woord en in strengheid op te tree en die gedrag van die verwonder nie uit sogenaamde ordentlikheid te verdra nie. Die motief mag egter nooit persoonlik wees nie.

\subsection{Perspektiewe op affiniteit}

In die lig van die onderlinge tweedrag in Korinte stel Paulus die volgende: 


\subsubsection{Vertikale affiniteit}

Gelowiges se verbondenheid aan Christus (vgl. 1 Kor. 1:9), eerder as ' $n$ verbondenheid aan bepaalde apostels (vgl. 1 Kor. 1:12), word die faktor wat eenheid verwerklik. Die besondere Christologie in 1 Korintiërs 1:17-25 kan ook as basis vir regstelling gesien word. Die eendersdenkendheid tussen gelowiges word verwerklik wanneer hierdie gelowiges hulle denkinhoude vorm in die lig van Christus se lering en voorbeeld. Paulus beklemtoon ook die wese van gelowiges, naamlik 'n tempel van die Heilige Gees (1 Kor. 3:16). Hy stel dan teen hierdie agtergrond dat tweedrag hierdie tempel beskadig.

\subsubsection{Onderlinge omsien na mekaar}

Die bestraffing deur die meerderheid word deur Paulus as 'n korrektiewe instrument gesien vir iemand wat droefheid veroorsaak het $(2$ Kor. $2: 5,6)$. Hierdie bestraffing loop uit op vergewing en bemoediging sodat die persoon wat bestraf word, nie so hartseer word dat hy heeltemal moed verloor nie (2 Kor. 2:7). Paulus voeg ook dié versoek by: "Bewys liefde aan hom" (2 Kor. 2:8). Die liefde is waarskynlik Paulus se vernaamste korrektief. Daarby word verdeeldheid in 'n gemeente teengewerk deurdat die lede gelyke sorg vir mekaar dra (1 Kor. 12:25). Binne die eenheid van die gemeente is al die lede met hulle verskeidenheid gawes op mekaar aangewese. Die onontbeerlikheid van onderlinge sorg word al sterker besef. Heystek (2000:125) sê dat die "mekaar-opdragte" onontbeerlik is vir die bevordering van 'n kerklike geloofsgemeenskap, en Van der Merwe (1995:64) stel dit so: "Dit is in die gemeenskap met medegelowiges dat ons gemeenskap met God tot volle ontplooiing kom." Die gemeente is 'n bron van energie, van potensiële bedieninge en 'n rykdom van gawes. Botha (1995:96) gebruik die begrip "energering" om die aksie te beskryf waardeur hierdie energiebron omgesit kan word in opbouende energie.

In hierdie artikel kan die eis van geloofsgemeenskap moeilik oorbeklemtoon word. Juis om hierdie rede is dit nodig om die aksie van gelyke sorg vir mekaar - soos Paulus dit stel in 1 Korintiërs 12:25 in verband te bring met sy uitspraak in Romeine 12:9-10, 13, 18 en 20. Sowel in Romeine 12 as in 1 Korintiërs 12 word die metafoor van die liggaam gebruik om sorg vir mekaar uit te druk. Tog word in Romeine 12:9-10, 18 en 20 'n verdere nuanse van belang vir ons tema bygevoeg. Verse 9-10 en 13 behandel onderlinge sorg en liefdesbetoon in die gemeente: die liefde moet opreg wees (vers 9); daar word versoek: betoon hartlike broederliefde teenoor mekaar, 
bewys eerbied teenoor mekaar (vers 10), help die medegelowiges in hulle nood (vers 13). Dit is opvallend hoe dikwels die gedagte van mekaar hier voorkom. Die eerste sirkel van liefdesbetoon is in die gemeente self, ook die gemeente waarin sowel die verwonder as die bedienaar lidmate is. Die beklemtoning van mekaar in verse 9-10 en 13 gaan in vers 17 oor in: wees goedgesind teenoor alle mense en in vers 18 in: leef in vrede met alle mense. Die gedagte van mekaar gaan oor in alle mense, en alle mense gaan oor in vyande (vers 20): "As jou vyand honger is, gee hom iets om te eet en as hy dors is, gee hom iets om te drink."

Die beklemtoning van onderlinge sorg en die ondersteuning van mekaar is dus vir die onderwerp wat in hierdie artikel betrek word, toepaslik. As sodanige sorg vanweë die patologie van die verwonder nie moontlik is nie, moet goedgesindheid nogtans bewys word. As die verwonder openlik vyandig is, moet hy selfs fisies ook nog versorg word. Wraak het geen plek in hierdie proses nie. Die gemeente het ook teenoor die verwonder 'n verantwoordelikheid. Net so is ook 'n deel van die onderlinge omsien na mekaar dat die gemeente ook die verwonde bedienaar sal opbeur. 2 Korintiërs 7:6, 7 stel dit duidelik: "Maar God wat die neerslagtiges opbeur, het ons ook opgebeur deur die koms van Titus, en nie net deur sy koms nie, maar ook omdat julle hom opgebeur het."

\subsubsection{Openhartigheid}

Paulus tree openhartig en eerlik teenoor sy lesers op (2 Kor. 1:12). Hy herhaal sy gesindheid teenoor hulle in 2 Korintiërs 6:11, 12: "Ons het openhartig met julle gepraat, Korintiërs. Ons harte is vir julle wyd oop. Ons het nie ons harte vir julle gesluit nie; julle het julle harte vir ons gesluit." Op grond van sy eie voorbeeld van openhartigheid teenoor sy lesers (vgl. ook 2 Kor. 7:4) kan Paulus dieselfde van hulle vra: "Doen aan ons wat ons aan julle gedoen het: maak julle harte ook wyd oop!" (2 Kor. 6:13). In ooreenstemming hiermee sê Paulus dat hulle (sy lesers) in sy hart is om op hierdie wyse met hulle saam te lewe en te sterwe (vgl. ook 1 Kor. 12:26). Op grond van hierdie voorbeeld kan hy ook aan hulle die versoek rig: "Maak vir ons plek in julle harte" (2 Kor. 7:2).

\subsubsection{Lae affiniteit}

Paulus maak 'n onderskeid tussen verskillende groepe binne die horisontale verhouding en hierdie onderskeid hou verband met 'n onderskeibare graad van affiniteit wat telkens van sy kant af gehandhaaf word. Met gelowiges staan hy in 'n verhouding van hoë 
affiniteit, maar met hardnekkige ongelowiges staan hy in 'n verhouding van baie lae affiniteit. Paulus stel 'n voorbeeld van 'n uiterste vorm van 'n lae affiniteit of verwerping wanneer hy "'n man wat met sy stiefma as man en vrou saamleef", aan die Satan oorgee (1 Kor. 5:3). Tog behou hy 'n hoë affiniteit teenoor gelowiges deur wie hy aangeval word. Paulus se reaksie op die aanvalle is nie persoonlik of selfhandhawend van aard nie, maar word enersyds gedra deur Paulus se vertikale verhouding en dien andersyds daartoe om die gemeente op te bou: "Julle dink seker lankal dat ons ons by julle probeer verdedig? Nee, ons praat in verantwoordelikheid aan God en in verbondenheid met Christus. Alles wat ons doen, geliefdes, is in belang van julle geestelike opbou" (2 Kor. 12:19).

\subsubsection{Liefde}

Die liefde wat veral in 1 Korintiërs 13 beskryf word, is 'n funksionele liefde en die doel daarvan is om verdeeldheid (wat interpersoonlike afstand impliseer) te vervang met dade wat in hulle bedoeling deur die liefdesmotief beheer word. Dit is 'n sterk deurlopende en allesbeheersende motief. Paulus sluit ook sy eerste Korintiërbrief af met die vermaning: "Laat alles by julle in liefde geskied" (1 Kor. 16:14) terwyl hy die tweede brief só afsluit: "En die God van liefde en vrede sal by julle wees! Groet mekaar met die soen van Christelike broederskap" (2 Kor. 13:11, 12). Hierdie liefde is 'n eienskap van God wat deur geloof en inlywing in Christus 'n eienskap van die mens word. Die objek van God se liefde is die mensheid (wêreld - Joh. 3:16), maar die doelwit van God se liefdesaktiwiteit lê in die vernuwing van die mens.

\subsubsection{Die betekenis van interpersoonlike affiniteit vir die onderwerp}

Paulus hanteer sy aanvallers in die veronderstelling dat die betrokke gemeente die volgende profiel vertoon (of behoort te vertoon):

- 'n Lidmatekorps wat in verbondenheid met Christus leef en ook die inwoning van die Gees beleef (vgl. 4.3.1), gaan ook in verbondenheid met mekaar leef. So 'n lewensinstelling gaan die kontras tussen die verwonder en die res van die gemeente soveel groter maak en hom gevolglik soos 'n seer vinger sal laat uitstaan. 'n Gemeente sonder eenheid in Christus, maar bloot met 'n nominale eenheid, gaan dit vir die verwonder makliker maak om agter 'n masker te funksioneer.

- 'n Kerk wat as 'n onderling versorgende en ook vermanende gemeenskap leef, is een van die belangrikste faktore in die 
hantering van die tipiese verwonder (vgl. 4.3.2). So 'n kerk wat onderling meeleef, gaan meebring dat die verwonder uitgeken en bestraf sal word in die hoop dat dit sal uitloop op vergewing en bemoediging. 'n Styl van akkommodering en liefde (vgl. 4.3.5) behoort steeds gehandhaaf te word, sodat die probleem nie gekompliseer word nie. Die lidmatekorps het ook 'n kritiese funksie waardeur hulle noulettend moet uitmaak of enige aanvalle op die bedienaar en predikant werklik substansieel is. Die onderlinge kontak en omsien na mekaar is van kardinale belang. Wanneer dit duidelik is dat die hardnekkige handhawing van ' $n$ verkeerde motief ter sprake is, behoort met strengheid opgetree te word (vgl. 4.3.4),

- Openhartigheid (vgl. 4.3.3) van die bedienaar se kant sal ook min twyfel oor sy motiewe by die lidmatekorps laat - 'n ingesteldheid wat onsubstansiële aanvalle deur die verwonder moeilik sal maak. 'n Onvoorwaardelike positiewe houding van die kant van die bedienaar is noodsaaklik en die bedienaar behoort hom nie te laat verlei deur moontlike negatiewe gedrag (selfs verwonding) van die lidmaat wat bedien word om sy houding daardeur te laat bepaal nie. So word die voorbeeld van die bedienaar ook 'n toerustingsinstrument. Strengheid deur die bedienaar in gevalle waar dit nodig is, word egter nie deur hierdie hoë affiniteit verswak nie.

\section{5. 'n Verstaansanalise en hanteringsriglyne - praktyk- teoretiese perspektiewe}

\section{1 Verstaan die situasie}

Die verwonder - en sy gedrag - behoort verstaan te word, ten opsigte van die volgende fasette daarvan:

- Sy patologie. Vir die verstaan van die optrede van die verwonder is dit nodig om sy patologie te verstaan, naamlik dat hy vanuit bepaalde psigiese determinante of motiewe optree. Hierdie motiewe hou verband met ' $n$ psigiese disposisie waardeur die ervaring van mag vir hom 'n vermindering van angs meebring. Alhoewel bogenoemde dinamika min of meer by alle mense voorkom, is dit in die geval van die verwonder 'n ekstreme en wanaangepaste manifestasie.

- Sy koue determinisme. Hier behoort in gedagte gehou te word dat die verwonder 'n baie beperkte spektrum van interpersoonlike style het en dat sy persoonlikheidstyl hoofsaaklik beperk is tot die vyandig-dominerende kwadrant (vgl. Figuur 1). Daar ontbreek 
dus 'n soepelheid om binne 'n bepaalde konteks vanuit 'n breër spektrum die gepaste styl aan te wend.

- Sy emosie. Die verwonder tree met sterk emosie op wanneer hy 'n vermindering van selfwaarde ervaar. Hierdie emosie behoort ook verstaan te word as die gevolg van wetmatighede.

\subsection{Hanteer die situasie}

\subsubsection{Die verwonder geïdentifiseer}

Greenfield $(2001: 54,59)$ noem dit een van die grootste probleme, naamlik dat die gemeente (of 'n groot deel daarvan) die verwonder nie kan identifiseer nie, maar hulle eerder deur hom laat manipuleer.

Identifisering geskied deur middel van norme. Wanneer norme vervaag en verwater, gaan identifisering soveel moeiliker plaasvind. Wanneer die norme van die sondige wêreld aangelê word, sal die verwonder nie maklik geïdentifiseer word nie, aangesien dominering eie aan hierdie sondige bedeling kan wees. 'n Gemeente wat leef in verbondenheid met Christus en wat sy styl aangeneem het, gaan die nodige kontras skep tussen die liefdevolle gelowige wat diensbereid en nederig leef (sonder basiese angste) en die verwonder wat met sy magsug teikens aanval en polemies optree.

Identifisering geskied ook makliker wanneer 'n gemeente (veral die ampsdraerskorps) 'n gesonde kritiese ingesteldheid het. 'n Wantrouige interpersoonlike styl (vgl. 3.3.2.3 hierbo) het ook 'n goed aangepaste vorm wat in die kerk baie funksioneel aangewend kan word.

\subsubsection{Die reaksie en gesindheid as die predikant teiken en verwonde is}

Die mate van ontwrigting en afbrekende kragte in 'n gemeente gaan nie alleen deur die verwonder se optrede bepaal word nie, maar ook deur die bedienaar se reaksie daarop. Die reël hier is dat 'n sondige antesedent nie 'n sondige respons mag ontlok nie. Indien dit wel gebeur, skep dit 'n dubbele probleem.

Dit is logies dat die predikant/bedienaar heel eerste die geldigheid van die aanval sal vasstel. Indien kritiek substansieel is, behoort hy die opregtheid te hê om dit te erken, die kritikus daarvoor te bedank en dit as 'n groeigeleentheid te sien. Vir die doel van hierdie artikel word egter veronderstel dat die tipiese verwonder 'n duidelik sondige agenda het. 
Die basisteoretiese beginsel van deursigtigheid (vgl. 4.3.3 hierbo) geld hier as stylaanwyser vir die bedienaar (vgl. Lutzer, 1987:31). Hierdie deursigtigheid gaan sy motiewe bo verdenking plaas en vertroue skep. Dit gaan 'n ongunstige klimaat vir die verwonder skep, of die identifisering van die verwonder soveel makliker maak. Die bedienaar se nederigheid (vgl. 4.2 .3 hierbo) gaan die moontlikheid van 'n magstryd kleiner maak.

Sondige gedrag of gedrag vanuit 'n sondige (selfsugtige) motief behoort egter nie deur die bedienaar met aggressie beantwoord te word nie (vgl. 4.3.4 hierbo). Hierdeur gaan hy homself blootstel en 'n persoonlike risiko loop. Indien sy motief verband hou met die evangelie en nie met eie gewildheid nie, sal hy daartoe bereid wees. Hoe gouer met strengheid opgetree word, hoe gouer word die saak aan die kaak gestel en die verwonder geïdentifiseer.

Hierdie situasie van verwonding kan dien as 'n geleentheid vir die bedienaar om ' $n$ voorbeeld te stel van 'n Christus-verbonde optrede (vgl. 4.2.2 hierbo). Die vertikale dimensie is noodsaaklik. Erkenning behoort gegee te word aan die Persoon van Wie hy sy roeping ontvang het, as die Een wat altyd sentraal en lewendig in sy lewe is.

Outokratiese optrede is teenproduktief (vgl. MacArthur, 1995:20). Mag word in ons leefwêreld dikwels met leierskap geassosieer. Daarom is die versoeking baie groot dat die predikant ook hierdie mag wat die gemeente met sy leierskap kan assosieer, misbruik (vgl. Engstrom, 1976:100)

In gevalle waar die predikant reformatoriese vernuwing inisieer, is dit belangrik dat hy die gemeente vooraf in liefde sal toerus daarvoor sodat hulle mede in beheer sal wees. Wanneer lidmate voel dat hulle in beheer is van dit wat met hulle gaan gebeur, is hulle ook meer oop vir oorreding (vgl. Hawkins, 1997:84). Dit gebeur juis dikwels in tye van gemeentevernuwing dat die verwonder die predikant as teiken uitsoek en toeslaan onder die dekmantel dat dit vir hom gaan om die eer van God.

Die aanbieding van hierdie teoretiese riglyne geskied met groot begrip daarvoor dat die praktyk dikwels die skynbaar gladde verloop hiervan anders dikteer. Die vasberadenheid en vermetelheid van die verwonder stel besondere hoë eise aan die predikant om 'n positiewe reaksie te toon. Dit kan selfs vir die predikant nie menslik moontlik wees om positief te bly nie - alleen die leiding van die Heilige Gees kan dit moontlik maak. 


\subsubsection{Die profiel van die gemeente}

Paulus se hantering van sy aanvallers gaan nie sonder 'n oproep tot die gemeente van Korinte om hulle verantwoordelikheid tot onderlinge omsien na en reghelp van mekaar na te kom nie. Hiervoor is dit nodig dat die gemeente sy aard as andersoortige gemeenskap (anders as die wêreld en anders as bloot 'n sosiale gemeenskap) sal besef en uitleef. Hierdie andersoortige aard en eienskappe mag egter nie bloot nominaal wees nie, maar wesenlik. Die inhoud van hierdie aard hou verband met die gemeente (kollektief en individueel) se verbondenheid met Christus (vgl. 4.3.1 hierbo). Hierdie verbondenheid met Christus gaan ook 'n sterk aandrang tot verbondenheid met mekaar wees. 'n Gemeente wat ingestel is op eensgesindheid gaan ook 'n sensitiwiteit ontwikkel vir enige ontwrigtende kragte wat hulle tot optrede noop, eerder as die passiewe ignorering van 'n situasie. Om Christus in 'n gemeente lewend en werklik te dien gaan dit moeilik maak vir die verwonder om (baie) skade aan te rig. Hierdie sentraalplasing van die lewende Christus kan soos volg gestalte kry:

- Die bedienaar verkondig die Woord van Christus

- Die ouderlinge bedien die gesag van Christus in die werklikheid van die gemeente se lewe;

- Die diakens maak die liefde van Christus sigbaar;

- Die res van die gemeente vertoon die styl van Christus.

\subsubsection{Die rol van die gemeente}

Wanneer die profiel van 'n gemeente Bybels en substansieel is, behoort die gemeente ook effektief en aktief te wees, maar dan nie aktief net in die sin van aktiwiteite soos verkopings, fondsinsamelings, gebou- en terreininstandhouding, ensovoorts nie, maar aktief ten opsigte van die opdrag om hulle verantwoordelikheid en roeping teenoor mekaar na te kom (die sogenaamde "mekaaropdragte"). Hierdie opdrag sluit ook in die omsien na die bedienaar in (vgl. 2 Kor 7:6, 7). Die meeste lidmate is grootliks onkundig oor die druk wat die bedieningsituasie op die predikant en sy gesin plaas. Die behoefte aan openlike en begripvolle ondersteuning is baie groot (vgl. London \& Wiseman, 1993:22).

Ampsdraers word dikwels as die enigste aktiewe lede in die gemeente gesien en hierdie vreemde kerkbeskouing behoort teëgewerk te word. 'n Bybelse kerkbegrip is belangrik vir die 
ontwerp van 'n praktykteorie met die oog op die hantering van spanning in 'n gemeente (Heystek, 2000:123).

Lidmate het nie alleen 'n verantwoordelikheid om as lede van dieselfde liggaam baie openlik teenoor mekaar te wees nie, maar ook om met strengheid teenoor mekaar op te tree (vgl. 4.3.4 hierbo), alhoewel dit steeds (en juis) in liefde geskied (vgl. 4.3.5 hierbo). Die liefde is onder andere bedoel as 'n korrektief. So word die gemeente 'n versorgende en vermanende gemeenskap.

Wat hier gestel is ten opsigte van die gemeente, geld in dieselfde mate vir die ampsdraers. Orde en liefde behoort deur ouderlinge en diakens verwerklik te word. Dit geskied deur beplande en toegespitste toerusting. Die kritiese funksie van die ouderlinge is veral hier van toepassing.

\section{Slot}

In hierdie ondersoek na die predikant as teiken en die patologie van sy verwonder, kan dié vraag gevra word: Wat kan daaraan gedoen word? Daarop is die oorheersende antwoord dat 'n meelewende gemeente die identifisering van die verwonder baie makliker gaan maak. In die mate wat die verwonder rehabiliteerbaar is, sal ' $n$ aktiewe gemeente eweneens daarin 'n groot rol kan speel. Die sensitiewe gemeente sal ook groter begrip vir en empatie met hulle predikant hê.

\section{Geraadpleegde bronne}

AIKEN, L.R. 1993. Personality. Theories, research and applications. Englewood Cliffs, NJ: Prentice-Hall.

ALLPORT, G.W. 1961. Pattern and growth in personality. New York: Holt, Rinehart \& Winston.

ANDREWS, J.D.W. 1991. The active self in psychotherapy. An integration of therapeutic styles. Boston, MA: Allyn \& Bacon.

BOTHA, D. 1995. Energering: Entoesiastiese medewerkers. (In Smit, A., red. Nuut gedink oor leierskap in gemeentes. Die begeleiding van 'n Christelike geloofsgemeenskap. Kaapstad: Lux Verbi. p. 28-29.)

CARSON, R.C. 1970. Interaction concepts of personality. London: Allen \& Unwin.

DUKE, M.P. \& NOWICKI, S. (jnr.). 1982. A social learning theory analysis of interactional theory concepts and a multidimensional model of human interaction constellations. (In Anchin, J.C. \& Kiesler, D.J. Handbook of interpersonal psychotherapy. New York: Pergamon. p. 78-94.)

EKMAN, P.C. 2001. Wounding, doubting and trusting in suffering. The Journal of Pastoral Care \& Counseling, 55(2):159-166.

EMERY, R.E. \& OLTMANNS, T.F. 1999. Essentials of abnormal psychology. Upper Saddle River: Prentice-Hall. 
ENGSTROM, T. 1976. The making of a Christian Leader. Grand Rapids, MI: Zondervan.

EYSENCK, H.J. \& EYSENCK, M.W. 1985. Personality and individual differences. A natural science approach. New York: Plenum.

GOLEMAN,D. 1997 Emotional intelligence. Why it can mattter more than IQ. New. York: Bantam.

GREENFIELD, G. 2001. The wounded minister. Grand Rapids: Baker.

GROUNDS, V.C. 1975. Humility. (In Tenny, M.C., ed. The Zondervan Pictorial Encyclopedia of the Bible. Grand Rapids: Zondervan, p. 3:222-224.)

HAWKINS, T.R. 1997. The learning congregation. A new vision of leadership. Louisville, Kentucky: Westminster John Knox.

HEYSTEK, P.H. 2000. 'n Prakties-teologiese ondersoek van die "mekaar"opdragte in die Corpus Paulinum met die oog op kerklike geloofsgemeenskap. Potchefstroom: PU vir CHO. (Ph.D.-proefskrif.)

HOROWITZ, L.M., DRYER, D.C. \& KRASNOPEROVA, E.N. 1997. The circumplex structure of interpersonal problems. (In Plutchik, R. \& Conte, H.R., eds. Circumplex models of personality and emotions. Washington DC: American Psychological Association. p. 347-384.)

HAWKINS, T.R. 1997. The learning congregation. A new vision of leadership. Louisville, Kentucky: Westminster John Knox.

KIESLER, D.J. 1996. Contemporary interpersonal theory and research. Personality, psychopathology and psychotherapy. New York: Wiley.

KRUGER, S.F. 2000. Menslike persoonlikheid en toerustende herderlike bediening. Aspekte van 'n metateorie, basisteorie en praktykteorie. Potchefstroom: PU vir CHO. (Th.D.-proefskrif.)

KRUGER, S.F. 2004. Verandering in die kerk. Maak seker jy verstaan dit. Middelburg Mp: Outeur.

LEARY, T.F. 1957. Interpersonal diagnosis of personality: A functional theory and methodology for personality evaluation. New York: Ronald.

LONDON, H.B. \& WISEMAN, N.B. 1993. Pastors at risk. London: Victor Books.

LUTZER, E.W. 1987. Pastor to pastor. Tackling problems of the pulpit. Chicago: Moody .

MacARTHUR, J. Jr. 1995. Rediscovering pastoral ministry. Shaping contemporary ministry with Biblical mandates. Dallas: Word Publishing.

MÖLLER, A.T., red. 1996. Perspektiewe oor persoonlikheid. Isando: Heinemann.

NEL, M. 2001. Ek is die verskil. Die invloed van persoonlikheid in die prediking. Bloemfontein: CLF.

PLUTCHIK, R. \& CONTE, H.R., eds. 1997. Circumplex models of personality and emotions. Washington, DC: American Psychological Association.

ROUX, G.B. 1992. Stressore in die bediening en die effek daarvan op spesifieke persoonlikheidsaspekte van die predikant. Ned. Geref. Teologiese Tydskrif, 33(2):225-232.

SAFRAN, J.D. \& SEGAL, Z.V. 1990. Interpersonal Process in Cognitive Therapy. New York: Basic Books.

SULLIVAN, H.S. 1953. The interpersonal theory of psychiatry. New York: Norton.

SULLIVAN, H.S. 1955. Conceptions of modern psychiatry. The first William Alanson White memorial lectures. London: Tavistock.

VAN DER MERWE, M. 1995. Nuwe treë saam met God. Riglyne en programme oor spiritualiteit en gemeentevernuwing. Kaapstad: Lux Verbi. 
VENTER, C.J.H. 2004. Die predikant wat houe uitdeel - die gemeente as teiken. In die Skriflig, 38(3):429-449.

WADE, C. \& TAVRIS, C. 2003. Psychology. Upper Saddle River: Pearson Education.

WEAVER, J.A. 2002. Mental health issues among clergy and other religious professionals: A review of research. The Journal of Pastoral Care \& Counseling, 56(4):393-403.

WIDIGER, T.A. \& CORBITT, E.M. 1995. Antisocial personality disorder. (In Livesley, W.J., ed. The DSM-IV personality disorders. New York: Guilford. p. 103-126.)

WIDIGER, T.A. \& HAGEMOSER, S. 1997. Personality disorders and the interpersonal circumplex. (In Plutchik, R. \& Conte, H.R., eds. Circumplex models of personality and emotions. Washington, DC: American Psychological Association. p. 299-325.)

WIGGINS J.S. 1996. The five-factor model of personality: Theoretical perspectives. New York: Guilford.

\section{Kernbegrippe:}

geloofsondersteuning van die predikant

persoonlikheidstipes, afwykend

predikant as teiken

verhoudingspanning in 'n gemeente

\section{Key concepts:}

minister as target

personality disorders

relational tension in a congregation

supporting the pastor within the community of faith 